\section{THE OAK TREE}

\section{BY ALEXANDER L. HOWARD}

"Stabat in his ingens annoso robore quercus; una nemus." (In aged majesty a mighty oak towers o'er the subject trees, itself a grove.)-Ovin.

$\mathrm{F}^{\mathrm{n}}$ ROM earliest times the oak tree has been held sacred by all people in all countries, and it is not surprising that it was worshipped by the rude and savage barbarians who inhabited Great Britain two thousand years ago, when Druids held their services under their sacred oaks. In comparison to their ignorant and primitive forms of worship it is good to think that these wild people were impressed by the solemn beauty of their great forests, where tall trunks of trees, roofed in with foliage, made natural cathedrals in the open air.

Apart from its beauty and grandeur the oak tree has played a vital part in the growth of our great Empire; in the reign of Queen Elizabeth our small battleships were built almost entirely of oak.

Boulger quotes it as having been the favourite timber of Greeks, Romans, and Norsemen--the latter having used it for the building of their long ships. He also tells us how the great iron industry of Sussex, which supplied the cannon for Elizabeth's Navy, relied for smelting upon an inexhaustible supply of British oak.

During the War of 1914-18, at a time of crisis, when foreign supplies of timber failed, the nation once again depended upon the faithful services of this mighty tree.

In a tree song which he dates A.D. 1200, Kipling says :

England shall bide till judgment tide,

By oak, and ash, and thorm.

Yet now that we have become in many respects a cultured and enlightened nation, there are ominous signs that the immense value and importance of the oak tree has been forgotten.

Those of us who have seen the great oaks that have been felled during the last twenty years cannot fail to have observed that there were definitely three outstanding plantings : the first, and most important, probably being self-sown, and dating back approximately twelve to fifteen hundred years; the second can be placed about 1450 ; and the third about 200-250 years ago. On the grassy bank beneath the church at Northiam, Sussex, can be seen two interesting examples-a venerable giant of the earlier date, and slightly lower down the bank a lesser giant, which probably belongs to the second era. Still lower there is a healthy youngster of about forty years, which, however, has been identified as a fine specimen of $Q$. Merbeckii, a semi-evergreen oak, native of northern Africa, which retains its leaves until the New Year. The Knightwood oak, near Lyndhurst, in the New Forest, still stands; until a year or two ago "The Twelve Apostles", in Lord Petre's Park, at Brentwood, Essex, and many other veterans were still flourishing. On Sir George Courthope's estate at Whiligh, near Tunbridge Wells, is an oals tree which can be best described in his own words :

"the old manorial map which showed a little picture of 'ye olde oake' in more or less its present condition, was dated 1493. The bark is most vigorous. When I was a child there was an opening over two feet wide into the hollow trunk, in which several persons could sit. The opening is now only a few inches wide."
Near by is another fine example, the age of which is unknown, but which I thought might belong to the second category of about 450 years ago. Sir George Courthope describes it as follows :

"The specimen oak today has a girth of exactly 15 feet five feet from the ground, and is practically cylindrical until the spring of the first two branches, just over thirty feet up. The stem continues from another 10 or 12 feet to the main spring of boughs. It still grows. In, I think, 1920, when the Royal Arboricultural Society first came here, Henry Elwes and Dr. Henry saw the tree for the first time. The girth was then just under 14 feet, and the volume of the $\log$ was calculated at 410 cubic feet. In 1914 a would-be buyer . . . offered me $£ 317$ f.o.v. . . . for the log up to the second spring of boughs, which they calculated at 634 cubic feet. The haulage of so great a log would have destroyed three-quarters of a mile of farm road and half a mile of carriage drive; so the tree still stands."

It would appear from Sir George Courthope's records that two other somewhat similar trees were taken from the west side of the house and used for the restoration of the Westminster Hall roof. The Clerk of Works to the House of Commons counted. more than five hundred annual rings in a squared beam (heartwood only) which was used for this purpose. About thirty years ago another specimen belonging to this category was felled at Danbury Palace, in Essex. This is referred to in "A Manual of the Timbers of the World" :

"it had five secondary trunks growing out of the butt, all of which were of a very rich brown colour. After the tree was sold a man was idly pulling out the decayed wood from a hollow in the side of the trunk, when he felt something hard, which he discovered was a small coin, after. wards found to be of Roman origin."

The authority H. J. Elwes was sceptical about these accounts of the great age of the oak tree-a doubt shared by Sir Geoffrey Evans-but as a result of years of careful study, despite the opinion of these two authorities, I still believe in them. Under the best conditions I think the oak continues to flourish for about five hundred years : apparently a further span of two hundred years follows, during which time little change is noticeable, and afterwards five hundred years or more will be passed before it reaches its last stage. A good example of this later condition can now be seen by the church at Hawkhurst, in Kent, where there is an old oak, its life finished, but the dead remains bricked in. One other, which is still producing a few shoots, can be seen by the church at Catsfield, in Sussex. The historic oak tree at Hatfield Park, now a hollow shell filled with concrete and fenced around (said to have been dead for about sixty-five years) can still be seen. According to tradition, it was under this tree that Queen Elizabeth was resting when she received the news of the death of her sister-Queen Mary. Every care has been taken to preserve it, and there is a tablet painted stating that it is the identical tree. There is every reason to accept this story, and if such be the case we may well believe that four hundred years ago the tree was flourishing, and it is likely that at that time it would have been more than $500-600$ years old. In the near neighbourhood, at Brocket Park, a tree still stands, which produces a good crop of leaves year by year. This tree is taken care of and valued for its antiquity. The butt, measuring 32 feet in circumference, is clothed with sound healthy bark to a height of 12 feet, where it breaks out with immense limbs, which still produce an abundance of 
rich green leaves. It has sometimes been claimed that it was under this tree that Queen Elizabeth received the news, but the history of Hatfield Park negatives the claim of Brocket Park.

Fifteen hundred years ago Pliny tells us :

"In the same North climate is the mightie forrest Hercynia. A huge and large wood this is, stored with tall and big okes, that never to this day were topt or lopt. It is supposed they have beene ever since the creation of the world, and in regard of their eternall immortalite surmounting all miracles besides whatsoever. And to let passe all other reports which happily would be thought incredible, this is knowne for certaine, that the roots of the trees there, run and spread so farre within the ground, that they encounter and meet one another: in which resistance they swell and rise upward, yea, and raise up mounts of earth with them to a good height in many places : or, where as the earth followeth not, a man shall see the bare roots embowed arch-wise, and mounting aloft as high as the very boughes: which roots are so interlaced, or else rub one against the other, striving (as it were) not to give place, that they make a shew of great portailes or gates standing open so wide, that a whole troupe or squadron of horsemen may ride upright under them in ordinance of battell."

For near 250 years the planting and conservation of the oak tree has almost ceased, and during this critical time prodigious demands have nearly destroyed the last reserves in Britein. Nor is this the worst. Before the War, the numerous country saw. mills found it a profitable business to handle small and immature trees, because the plant at their disposal was unsuited for the larger sizes. Meeting a vigorous demand caused by the ever-increasing building operations which have continued since the War of 1914-18, and finding owners hard put to it for death duties and increased taxation, great numbers of oak trees of 60-150 years growth have been reluctantly sacrificed. Indeed, since the present War began, whole tracts of beautiful woodlands have been ruthlessly cut down, quite regardless of size and age, and a host of parks throughout the country have been denuded of timber-like trees.

At three successive periods of our history, the Government or the reigning monarch has recognized the urgency of the situation, so that in the reign of Edward I, again in Elizabeth's time, and lastly in Charles II and James II reigns, laws were passed prohibiting the felling of trees. We read of how Samuel Pepys was greatly troubled on account of a strange situation concerning the Duke of Albemarle and the Earl of Clarendon with regard to the oak trees in Clarendon Park. Pepys notes in his Diary on July 23, 1664, that he would "rather fling away the gains of $£ 2,000$ or $£ 3,000$, than have it said that the timber which should have been the King's... was concealed by us in favour of my Lord Chancellor". It would be well if the same spirit which animated the people of those days could be revived again to-day. The fierce flame which burnt in those stormy times is illustrated by the action of the Duchess of Monmouth, who took revenge on King James after her husband had been beheaded, by cutting in half all her oak trees at Moor Park, in order that the timber should not be employed in the building of the King's ships.

The debate in Parliament (1943) possibly marked the second occasion only in more than a hundred years, when this subject of such vital importance to the State received the attention of the Government. One fact alone which emerged should open many eyes, and that is that the soil and climate of Britain can and will produce a growth of forest wealth as good and better than any other country of similar character.

It would, of course, be ridiculous to plant the oak tree in uncongenial areas; but it should be planted, and planted again continuously, in those soils and counties where it flourishes. Natural regeneration of oaks occurs year after year, and trees so produced have a sturdier and better growth than anything that can be planted. Such areas should be preserved by law, as they have been for years past in southern Europe and elsewhere. No person or municipality should be allowed to cut down any tree, either mature or immature, unless he can prove to the recognized authority that he has planted at least five to take its place, or alternatively, that he has wired against vermin and preserved a naturally regenerated area of equal value.

Elwes mentions in "Timbers of Great Britain and Ireland" innumerable species of oak (Quercus sp.) as established in Great Britain, but in this article I shall confine myself to four which I consider the most important, namely, Q. pedunculata Ehrh.; $Q$. sessitiflora, Salisbury; $Q$. Cerris, Linn. ; $Q$. Lucombeana (Sweet).

$Q$. pedunculata is represented by many thousands of trees in all parts of England, Wales and Ireland, and in a smaller degree in Scotland. These trees are of all ages, sizes, and in all conditions, but alarmingly reduced in number throughout the last 50-70 years. To-day $Q$. sessiliflora is rare, and a careful search and inquiry carried out during the last forty years convinces me that it has never been abundant in Great Britain. Mr. D. W. Young, the deputy surveyor of the New Forest, tells me that there are considerable tracts in certain parts, but $I$ and many others who have sought for them have never been successful in our search, and I think this species has been introduced from the Continent, an opinion which is shared by others. In beauty as well as in timber, despite the controversy which has persisted since the time of wooden ships and the writings of Laslett, we can safely say that these first two species have equal merit.

In strength and durability there is nothing grown in our country which can compare with British oak, and indeed, although the oaks of America, Canada, Northern and Southern Europe, Japan, etc., are very numerous and approach equality, it may be safely affirmed that the British oak is pre-eminent. In the days when our stout ships travelled the seas, there was nothing else that could have been found strong and sturdy enough to provide the main structure and the planks, and we have an intensely interesting and informative account of the manner in which the utmost care was taken to bring into use the huge branches with their gnarled and twisted growths, so that the limbs of the crown of one single tree were of more value than the huge trunk which supported them.

The Rev. C. A. Johns tells us about a tree which was felled in the New Forest :

"It stood singly in the wood, and extended its massive branches nearly 40 feet each way. Its head was all knees and crooks, aptly suited to naval purposes; its bole or shaft was short, not exceeding 20 feet in length; but it was full 6 feet in diameter at the top, and perfectly sound. It was felled in an unusual manner for the preservation of its crooks, which were cut off one by one whilst the tree was standing, and lowered by tackles, to prevent their breaking. The two largest arms were sawed off at such distances from the bole as to make first rate knees; scaffolds were then erected, and 2 pit saws being braced together, the body was first cut across, half through at the 
bottom, and then sawed down the middle, perpendicularly between the two stumps of arms that had been left, at the end of one of which stood a perpendicular bough, bigger than most timber trees. To prevent this being injured a bed was made of some hundreds of faggots to eatch it when it fell. This half was so weighty that it crushed a new timber carriage all to pieces the instant it was lodged upon it; and none in the country being found strong enough, the King's carriage was sent purposely from Portsmouth to convey it to the Dockyard. This tree

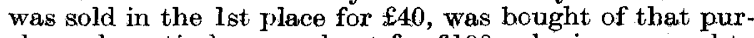
chaser by a timber merchant for $£ 100$, who is supposed to have cleared $\$ 100$ more; which he might very well do, for the contents amounted to 32 loads of hewed timber, which at $2 / 6$ a foot--no unusual price for naval crooksamounts to $£ 200$ precisely, besides faggots ete. sufficient to defray expenses. The breadth of the tree across near the ground, where it was cut was 12 feet."

It is impossible to catalogie the great number of uses for which oak is preferable to any other British home-grown woads, nor is it necessary, as its qualities are so widely known. Perhaps, however, its uses for panelling or general interior decorative woodwork are not sufficiently recognized. When it was first used in this capacity the superiority of English-grown oak aver that of foreign arigin was apparent. By degrees its merits appear to have been forgotten, so that importations of foreign competitors became fashionable. Proprietors, proud of their rich inheritance of real old English oak panelling, recognized its value, but new aspirants failed to understand that imported oak was not comparable with British. There is no oak obtainable from any part of the world which will assume the rich golden colour or the attractive figure of English-grown oak, which should not be polished, but left from the tool. Quoting from " $A$ Manual of the Timbers of the World", p. 364:

"When certain individual British oak trees (Quercus Robur) are felled, their ardimary heart-wood is found to be partially or wholly thanged into a richer toned reddishbrown wood which is known as 'brown-oak'. It was formerly, and indeed it is oceasionally even now, among English timber merchants and others in this country, called 'red oak'. The colour is much like that of polished crocodile leather, very variable in character, depth, and richness. It may be uniformly of a comparatively light brown, or again a deep rich brown, haxing in some cases lighter streaks; while in some portions from one to two inches wide, the ordinary colour does not appear to have been affected at all; egain, the warm brown may be spotted and streaked with almost black veins, presenting a rich appearance. This last form is called 'tortoiseshell' pattern."

The beauty and usefulness of this brown oak has never been properly appreciated in England, but curiously enough the demand from America has been persistent and considerable. To meet this demand during the last half-century many thousands of the oldest and best trees which we possessed have been shipped across the Atlantic.

It is commonly known that the sapwood of oak should never be included with any woodwork requiring a long life. The sapwood decays very rapidly, and moreover it is particularly liable to attack by the Lyctus and Zestobium beetles, and fungi. The attack from beetle will often begin within a yoar after the work has been finished, and will certainly appear in the course of years. Having started, it will invariably spread to the heartwood, and it is therefore essential that sapwood should be entirely exclud. ed. Hitherto it has been rare to find any oak woodwork which has beon installed, completely free from the inclusion of sapwood, and the failure to insist upon this practice has been the cause of most, if not all, of the trouble which has been experienced.

With reference to durability, Elwes tells us :

"Many cases have been recorded and published of the great durability of the timber of the oak under ground and under water; but I have come across no relic of the past so interesting in this respect as the prehistoric boat which was dug up at Brigg, in Lincs. in 1884. This wonderfully preserved dug-out was hollowed out of one huge oak log 48 $\frac{1}{2}$ feet long and approx : 6 feet in diameter, which showed no signs of branches, a $\log$ which must have contained nearly $1000 \mathrm{ft}$. of timber, and which could not be matehed now in England, or so far as we know, in Europe or N. America. The boat is $4 \mathrm{ft}$. 3 ins. wide by $2 \mathrm{ft} .8 \mathrm{ins}$. deep at the bows, and $4 \mathrm{ft}$. 6 ins. by $3 \mathrm{ft} .4$ ins. at the stern, which was the root end of the tree. The sides are about 2 inches thick, the bottom 4 inches at the bows, and as much as 16 inches at the stern. One stern piece was ingeniously fitted in, though not found in situ, and a large rift on one side had been still more cleverly repaired with wooden patehes caulked with moss. No metal had been used in any part of it. The boat was found imbedded in the blue \& brown elay which underlies the peat, and is eonsidered on geological evidence, which is given with great detail, to be from 2600 to 3000 years old."

The Lucombe oak (Q. Lucombeana (Sweet)) produced something of a sensation in arborieultural ciroles when in 1773 William Boutcher wrote as follows :

"About 7 years since, Mr. Lucombe of St. Thomas near Exeter, sowed a parcel of acorns, saved from a tree of his own growth, of the iron or wainscot species. When they came up he observed one amongst them that kept its leaves throughout the winter. Struck with the phenomenon, he cherished and paid particular attention to it; he propogated it, by grafting some thousands from it, which I had the pleasure of seeing, 8 days ago, in high flourishing beauty and verdure, notwithstanding the severity of the winter. Its growth is straight, and handsome as fir; its leaves evergreen : and the wood is thought by the best judges, in hardness and strength to exceed all other oaks. It makes but one shoot in the year, viz. in May, and continues growing without intermission: whereas other Oaks shoot twice, viz. in May and in August. But the peculiar and inestimable part of its character is, the amazing quickness of its growth which I imagine may be attributed (in some degree at least) to its making but one shoot in the year : for, I believe, all trees that shoot twice are some time at rest before they make the second."

Although Boutcher reported the oak as evergreen, it is more correctly described by Elwes as "sub-evergreen", retaining its leaves until the following year.

It appears that Mr. Lucombe had in his nursery a specimen tree of the cork oak (Q. suber) near a specimen tree the Tarkey oak, Q. Cerris, and that he concluded that the flowers were pollinated by the cork tree. This opinion was afterwards confirmed by Sir Hugh Beevor, who raised a similar tree under the same conditions. Messrs. Salter, Simpson \& Sons, of Attleborough, have informed me under date of Feb. 1, 1944, that the tree Sir Hugh Beevor showed me forty-five years ago still flourishes, and that its present height is 45 feet, with a circumference of 3 feet 6 inches at 5 feet from the ground. The supposition that the tree is a hybrid of $Q$. cerris and $Q$. suber, which has produced such a remarkably fine timber, proves that we have been both idle and unenterprising, for in truth the wood of the Lucombe oak, if available, might have taken the place of foreign imports, and so released our shipping and inereased our revenue. Little data exist upon which to base definite assertions; but the information we have goes to prove that this wood surpasses in 
strength and durability more costly varieties that have been imported from abroad.

Elwes tells us that it is doubtful when $Q$. Cerris, or the Turkey oak, was introduced into Great Britain, but since neither Evelyn nor other authorities up to his time mention it, we may safely assume that its introduction dated from about two hundred years ago, when it became very popular throughout the south of England.

English landscape and parklands have a worldwide reputation, and one of the most noticeable and characteristic features is the Turkey oak, which has a grace and beauty all its own. As Elwes emphasizes, it grows not only faster but also straighter than other oaks, and although somewhat similar in appearance there is a subtle difference. The rugged dark-coloured bark first attracts attention, which is afterwards turned towards the noble crown, more widely spreading than the common oak and adorned with a richer green and jagged leaf. The tree produces a very pretty mossy-cupped acorn. The colour of the timber is similar to that of the common oak. It has a bad reputation among craftsmen, as it is harder and heavier to work and more inclined to split in seasoning. It contains a larger proportion of sapwood than the common oak, the outer line of which quickly perishes. The inner line, when carefully dried off, becomes as hard and durable as the heartwood. I am inclined to think that it has boen used in the place of ordinary oak, and despite the difficulties already mentioned, I believe that with proper treatment it would be found as useful and durable as other kinds.

In Norway, Sweden and Finland, where the forest wealth plays a most important part in the economic life of the countries, I understand a day is set apart when men, women and children sot forth to plant trees. For nearly two hundred years the people of England have enjoyed or been spoilt by a pnosperity unequalled, if not unsarpassed, by any other country except Ameriea, which ominously reminds us of the state existing in the Roman Empire 1800 years ago. Tne contrast between the action of our forefathers, to whom we owe the inheritance of our woodlands, and later generations, is nowhere more clearly seen than in the direction of reafforestation.

I have been told that in the eighteenth century Admiral Collingwood used to walk out with his pockets full of acorns, which he distributed over his estate, and the owner of that country, which includes what is now called Chanctonloury Ring, used to ride or walk to the top of the hill every day during the season and sow beech mast or plant a tree.

No words of mine can better express the policy which should be adopted by the State to-day than those written by Evelyn 260 years ago :

"And if thus His Majesty's forests and chases were stored, viz. with this spreading tree at handsome intervals .. benignly visited with the gleams of the sun ... nothing could be more ravishing. ... We should find such goodly plentations for the boast of our rangers, and forests infinitely preferable to anything we have yet beheld, rude and neglected as they are today, when his Majesty shall proceed, .... to animate the laudable pride into fashion, forests \& woods .... will present us with another face, than now they do. And here I cannot but applaud the worthy industry of old Sir Harbotle Irmistone, whe I am told from a very small nursery of acerns which he sowed in the neglected corners of his grounds did draw forth such numbers of Oaks of competent growth ... and did wonderfully improve both the beauty and the value of his desmesnes."

\section{TESTING WOOD PRESERVATIVES}

N $\mathrm{N}$ artiele by J. Loutritz (Bell Lab. Rec., 22, No. A 4 ; December 1943) describes laboratory and outdoor tests made on wood preservatives used for impregnating polos for communication lines. Sticks $\frac{3}{4}$ in. square and about $3 \mathrm{ft}$. long are cut from boards of southern pine sapwood, the uniform size of these samples facilitating calculation of the wood density and the amount of preservative retainerd, as both are based on volume.

Laboratory tests on preservatives are now earried out in an experimental cylinder by either full- or empty-cell methods. For the former, the air is evacuated from the eylinder containing the specimens, and after a specified time the cylinder is filled with preservative, air pressure being applied to force the latter into the wood cells; about $30 \mathrm{lb}$. of preserv. ative can be injected per cu. ft. of wood. In the emptycell treatment the cylinder air pressure is raised to from 25 to $50 \mathrm{lb} / \mathrm{sq}$. in. Then the preservative is pumped in, and the pressure is raised still higher to force the preservative into the wood. Upon releasing the pressure, the expansion of the initial air trapped by the preservative forces out the excess from the wood, and theoretically only the cell wall is coated. Vacuum is applied after the pressure is released to empty the cells more eompletely. The initial air pressure largely determines the amount of preservative which will be forced out of the cells, while the difference between the initial and final pressures controls the distribution and penetration.

About twenty sticks are selected for each charge and the sample is weighed before and after treatment, the gain being taken as the basis for calculating the amount of preservative retained. Then the sticks are cut at the centre to give specimens treated under identical conditions for comparison by the laboratory rot test and by field exposures. For field-exposure tests the specimens are buried to a depth of 7 in. in a uniform distribution throughout the test plot. They are examined once a year and the amount of decay at and below the ground-line is rated. Since some specimens survive several years or do not fail under exposure tests, a time rating was devised which takes into consideration their past performance.

When a preservative shows promising results in laboratory and field tests, larger material of fencepost size and eventually $10 \mathrm{ft}$. posts are treated and exposed in 'test gardens'.

\section{ELECTROSTATIC ELECTRON LENSES}

A $\mathrm{N}$ article by $\mathrm{K}$. Spangenberg and L. M. Field (Elec. Comm., 21, No. 3; 1943) describes and discusses the measured characteristics of a number of electrostatic lenses, giving the characteristic curves of nine different lenses belonging to three basic types. The forms tested were cylinder lenses of various spacings and diameter-ratios, aperture lenses (parallel plates with circular apertures on the beam axis) of various spacings, and, for comparisons, a lens formed by a cylinder and an aperture in a plate. By interpolating between the sets of curves given, approximate predictions of the properties of lenses of slightly different spacings or diameter-ratio may be made. The test method employed makes use of a 